Volume 18 Number 2 December 2018. p.459-480

https://doi.org/10.30603/au.v18i2.536

\title{
Kepemimpinan Perempuan di Ruang Publik dalam Tafsir Al-Kasysyâf
}

\author{
Sulaiman Ibrahim \\ IAIN Sultan Amai Gorontalo
}

\begin{abstract}
This paper explores al-Zamakhshari's thoughts on women's leadership in the public sphere in tafsir al-Kasysyaf's. Islam does not require the wife to submit to her husband as he is obliged to submit to God. On the contrary, with the existence of rights that must be fulfilled by the husband towards the wife, then as reciprocity of Islam gives the right for the husband to be obeyed as long as it does not conflict with the teachings of religion. However, in terms of leadership in the public sphere, azZamakhsyarîy is more likely to place the position of women under men. This is evident in his expression when interpreting the word فضل الله بضه علي بعض that leadership is given by Allah to men because of its advantages in several respects, even az-Zamakhsyarîy considers men to have many advantages over women
\end{abstract}

\begin{abstract}
Abstrak
Tulisan ini mengeksplorasi pemikiran al-Zamakhsyari tentang kepemimpinan perempuan di ruang publik dalam tafsir al-Kasysyaf. Islam tidak sampai menyuruh isteri untuk tunduk kepada suami sebagaimana wajibnya ia tunduk kepada Tuhan. Sebaliknya, dengan adanya hak-hak yang harus dipenuhi oleh suami terhadap isteri, maka sebagai timbal balik Islam memberikan hak bagi suami untuk ditaati selama tidak bertentangan dengan ajaran agama. Namun, dalam hal kepemimpinan di ruang publik, az-Zamakhsyarîy lebih cenderung menempatkan posisi kaum perempuan di bawah kaum pria. Hal ini tampak pada ungkapannya ketika menafsirkan kata بها فضل الله بعضهم علي بعض bahwa kepemimpinan itu diberikan oleh Allah kepada pria karena kelebihannya dalam beberapa hal, bahkan azZamakhsyarîy menganggap kaum pria mempunyai banyak keunggulan ketimbang perempuan.
\end{abstract}

\section{Kata Kunci: Kepemimpinan, Perempuan, Tafsir Al-Kasysyâf}

\section{Author correspondence}

Email: sulaiman@iaingorontalo.ac.id

Available online at http://journal.iaingorontalo.ac.id/index.php/au/index 


\section{A. Pendahuluan}

Tafsir Alquran dalam sejarah pertumbuhan dan perkembangannya telah mengalami dinamika yang cukup bervariasi. Hal ini sangat dimungkinkan karena tafsir merupakan hasil karya manusia, sehingga terjadinya keanekaragaman dalam corak penafsiran dan merupakan suatu hal yang tidak terhindarkan. ${ }^{1}$ Dari berbagai corak tafsir tersebut melahirkan metodologi tafsir, dan dengan metodologi tafsir itulah menuntun umat Islam dalam memahami Alquran secara akurat. Bahkan untuk lebih menunjang upaya penafsiran tersebut dibutuhkan tekhnik interpretasi khusus.

Sehubungan dengan hal tersebut, dalam upaya memahami Alquran secara utuh dan komperhensif, maka para pengkaji Alquran haruslah mengenal empat komponen dasar, yaitu; pengetahuan terhadap Alquran, pengetahuan tentang kaidah-kaidah tafsir, pengetahuan tentang metode-metode tafsir dan pengetahuan tentang kitab-kitab tafsir dan mufasirnya. ${ }^{2}$ Dari hal ini penulis memahami bahwa kajian secara utuh dan komperhensif terhadap kandungan pokok Alquran adalah sangat urgen, baik kajian terhadap kitab tafsir klasik maupun kitab tafsir modern.

Isi kandungan Alquran sedemikian kompleksnya membahas seluruh aspek kehidupan umat manusia. Salah satu konsep yang tertuang dalam Alquran yang menjadi pokok bahasan penulis adalah mengenai kepemimpinan kaum perempuan dengan merujuk kepada salah satu tafsir yang bercorak kebahasaan yaitu tafsir alKasysyâf dengan penulisnya az-Zamakhsyarîy.

Dalam Islam, persoalan memimpin ini merupakan persoalan yang tidak mudah. Sebab, ia memerlukan tanggung jawab yang tidak ringan, bahkan lebih jauh, harus dipertanggungjawabkan di hadapan Allah. Tanggung jawab kepemimpinan bukan hanya sekedar mempertanggungjawabkan terpenuhinya kebutuhan lahiriyah, seperti ketenteraman, kesejahteraan dan kepuasan duniawi lainnya, tetapi masih terdapat tanggung jawab yang sifatnya lebih mendasar; yakni tanggung jawab ruhaniah, baik yang dilakukan oleh diri pemimpin dalam

${ }^{1}$ H. M. Nur Kholis Setiawan, Tafsir Sebagai Resepsi al-Qur'an; Ke Arah Pemahaman Kitab Suci dalam Konteks Keindonesiaan. http://digilib.stital.ac.id/repository/tafsir-keindonesiaan_kholis.pdf. Diakses pada 15 Desember 2018.

${ }^{2}$ M. Quraish Shihab Membumikan Al-Quran, h. 154. Lihat juga Sulaiman Ibrahim, I'jāz Al-Qur'ān: Menelusuri Bukti Keotentikan Al-Qur'an, Farabi, Vol. Volume 12 Nomor 1 Juni 2015, h. 44. 
melaksanakan proses kepemimpinannya, atau yang dilakukan oleh anggota keluarga/masyarakat yang berada di bawah kepemimpinannya.

Posisi perempuan yang ditempatkan sebagai subordinasi pria sesungguhnya muncul dan lahir dari sebuah bangunan atau peradaban yang dikuasai pria, sehingga perempuan tidak diberi kesempatan untuk mengaktualisasikan dirinya berperan dalam posisi-posisi yang menentukan. Alasan kedua bahwa hadis yang dijadikan dasar tidak bolehnya perempuan menjadi seorang pemimpin itu adalah dalam kerangka pemberitahuan Nabi Saw., bukan dalam kerangka legitimasi hukum. Hadis ini apabila diperhadapkan dengan fakta-fakta sejarah sama sekali tidak dapat dipertahankan. Sejumlah kaum perempuan telah terbukti mampu memimpin bangsanya dengan sukses gemilang. ${ }^{3}$ Misalnya, Ratu Balqis, penguasa negeri Saba' yang telah menciptakan negeri yang adil makmur, negeri yang diberi gelar oleh Alquran baldatun thayyibatun wa rabbun ghafûr. Dalam dunia modern dikenal Indira Gandhi, Benazir Butho dan beberapa nama lainnya, sementara tidak sedikit kaum pria yang gagal dalam menjalankan roda pemerintahannya. Hal ini berarti bahwa jenis kelamin bukanlah penentu kesuksesan dalam memimpin, tetapi lebih pada sistem yang diterapkan dalam pemerintahannya.

Dalam pandangan ulama fiqih, peran politik pria dan perempuan dalam arti amar ma'ruf nahi munkar adalah memiliki kapasitas yang sama. Akan tetapi dalam arti politik praktis yang didalamnya diperlukan pengambilan keputusan yang mengikat (al-wilâyah al-mulzimah) menyangkut masyarakat luas, seperti pengambil keputusan dalam peradilan (menjadi hakim), dalam lembaga legislatif dan eksekutif atau kekuasaan besar atau publik (al-wilâyah al-udzmah), maka tugas-tugas tersebut tidak dapat diberlakukan secara sama. Misalnya dalam wilâyah al-qadhâ', para fuqaha telah menetapkan beberapa persyaratan, yaitu: muslim, berakal, dewasa, merdeka, sehat jasmani, adil dan memahami hukumhukum syari'ah. Sementara persyaratan jenis kelamin masih diperdebatkan. Pertama, Malik bin Anas, Syafi'i dan Ahmad bin Hanbal menyatakan bahwa perempuan tidak boleh menjadi hakim. Alasannya karena seorang hakim

${ }^{3}$ KH. Hussein Muhammad, Perempuan Islam dan Negara Pergulatan Identitas dan Entitas. (Yogyakarta: Qalam Nusantara, 2016), h. 42. 
disamping harus selalu menghadiri sidang-sidang terbuka yang di dalamnya terdapat kaum pria, ia juga harus memiliki kecerdasan akal yang prima, padahal tingkat kecerdasan perempuan lebih rendah dibanding tingkat kecerdasan kaum pria dan akan dapat menimbulkan fitnah (gangguan). Kedua, mazhab Hanafi dan Ibnu Hazm adh-Dhahiri mengatakan bahwa pria bukan syarat mutlak untuk kekuasaan kehakiman. Perempuan boleh menjadi hakim, tetapi hanya mengadili perkara-perkara ringan, ini dikarenakan perempuan dibenarkan menjadi saksi. Pendapat mereka juga didasarkan kepada keputusan Umar bin Khattâb yang pernah mengangkat perempuan menjadi seorang bendahara pasar. Ketiga, Ibnu Jarîr al-Thabarîy dan Hasan Bashri berpendapat bahwa perempuan boleh menjadi hakim dan mengadili segala macam perkara. Mereka beralasan bahwa kalau perempuan boleh menjadi mufti, maka otomatis perempuan pun boleh menjadi hakim karena tugas-tugas yang diembannya sama. ${ }^{4}$

Dari beberapa uraian pendapat di atas, penulis mencoba mengkaji pemikiran az-Zamakhsyarîy ${ }^{5}$ yang dituangkannya dalam tafsir al-Kasysyâf. Dalam pembahasan ini penulis fokuskan mengenai kepemimpinan perempuan dengan merujuk kepada pendapat az-Zamakhsyarîy. Hal inilah yang akan penulis ungkap dari penafsiran-penafsiran az-Zamakhsyarîy.

\section{B. Kontroversi Kepemimpinan Perempuan}

Secara umum dapat dikatakan bahwa kontroversi ulama mengenai kepemimpinan perempuan berawal dari pandangan tentang asal kejadian perempuan. Pemahaman tentang asal kejadian perempuan ini membawa kepada kontroversi pemikiran tentang kepemimpinan perempuan. Hal ini dapat dipahami dengan melihat potensi dan fitrah yang dibawa oleh perempuan yang akhirnya akan berimplikasi terhadap pemahaman tentang kemampuan perempuan untuk menjadi pemimpin.

${ }^{4}$ KH. Hussein Muhammad, Perempuan Islam dan Negara, h. 125.

${ }^{5}$ Nama lengkap Al-Zamkhsyari adalah Abu al-Qasim Mahmud bin Umar bin Muhammad bin Ahmad bin Umar al-Khawarizmi al-Zamakhsyari dan ia dijuluki Jarullah ( tetangga Allah ), karena ia pergi ke Makkah dan tinggal di sana lama sekali . Ia lahir pada hari Rabu tanggal 27 Rajab $467 \mathrm{H}$, bertepatan dengan tahun 1074 M di Zamakhsyar, suatu desa di Khawarizmi, terletak di wilayah Turkistan, Rusia. Ia hidup di lingkungan sosial yang penuh dengan suasana semangat kemakmuran dan keilmuan. Dan beliau wafat pada tahun 538 H, setelah ia kembali dari Makkah. Amin al-Khuliy, Kasysyâf az-Zamakhsyarîy (Mesir: Maktabah al-Usrah, t.th.), h. 5, Muni' Abdul Halim Mahmud, Manâhij alMufassirûn (Beirut: Dâr al-Kutub, 1978), h. 105 
Sa'id Hawwâ, Salah seorang ulama tafsir juga memberikan tanggapan tentang penciptaan perempuan. Akan tetapi pendapat yang diungkapkan oleh Sa'id Hawwâ tidak berbeda dengan pendapat al-Alûsi. Kalau ada tambahan, hanyalah kutipan pendapat Ibnu Abbâs yang mengatakan: "Perempuan diciptakan dari lakilaki, oleh sebab itu kegairahannya ada pada laki-laki, dan diciptakan laki-laki dari tanah, maka dijadikan kegairahannya pada bumi, maka jagalah perempuanperempuanmu" (Riwayat Ibnu Abi Hisyâm). ${ }^{6}$ Setelah mengutip Ibnu Abbâs, Sa'id Hawwâ menegaskan penolakannya terhadap segala macam pemahaman lain terhadap kalimat wa khalaqa minhâ zaujahâ. ${ }^{7}$ Sementara itu al-Marâghi8 berpendapat bahwa Hawa diciptakan dari nafs wâhidah (artinya jenis yang satu atau jenis yang sama), sehingga tidak ada perbedaan antara penciptaan Adam dan Hawa. Menurutnya, ayat-ayat Alquran sedikitpun tidak mendukung pemahaman yang beranggapan bahwa Hawa diciptakan dari tulang rusuk Adam, sebagaimana ditemukan dalam beberapa riwayat.

Berdasarkan pada surah an-Nisâ' ayat 34 tersebut, Al-Alûsi dan Sa'id Hawwâ juga sepakat menyatakan bahwa suami adalah pemimpin terhadap isterinya dalam rumah tangga. Kalimat kunci yang menjadi landasan mereka adalah الرجال قوامون علي النساء. Oleh Al-Al-Alusi dalam memberikan komentar tentang menyatakan bahwa maksud ayat tersebut adalah bahwa kaum laki-laki adalah pemimpin kaum perempuan, sebagaimana pemimpin memimpin rakyatnya, yaitu dengan perintah, larangan dan semacamnya. Sedangkan Sa'id Hawwâ menafsirkan bahwa bahwa kaum laki-laki berfungsi sebagai yang memerintah dan melarang kaum perempuan, sebagaimana pemimpin berfungsi terhadap rakyatnya. ${ }^{9}$

Setelah kekuatan fisik dan kesempurnaannya, laki-laki juga memiliki kelebihan atas perempuan dalam hal kekuatan akal dan kejernihan pemikiran. Laki-laki dianggap sebagai sebuah potret yang lebih mampu berkreasi, berusaha dan mengatur urusan. Itulah sebabnya mereka diwajibkan untuk memegang

\footnotetext{
6Sa'id Hawwâ, al-Asâs fî at-Tafsîr, Jilid II (Cet. II; Kairo: Dâr as-Salâm, 2011), h. 986.

${ }^{7}$ Ibid., h. 987.

${ }^{8}$ Abdul Halim Mahmud, Manâhij al-Mufassirûn (Cet. I; Kairo: Dâr al-Kitâb al-Mishri, 1998), h. 339.

9'Sa'id Hawwâ, al-Asâs fî at-Tafsîr, Jilid II, , h. 1053.
} 
pimpinan dalam kehidupan rumah tangga. Sebab, setiap masyarakat perlu pemimpin untuk mempersatukan kemaslahatan umum.

Sa'id Hawwâ dalam memberikan komentar tentang kenapa seorang lakilaki menjadi pemimpin, pandangannya sama dengan pandangan az-Zamakhsyarîy. Akan tetapi Sa'id Hawwâ menambahkan alasan yaitu bahwa kesempatan laki-laki untuk berpuasa selama bulan Ramadhan dan salat setiap hari. Berbeda dengan perempuan yang tidak bisa melaksanakan seperti laki-laki karena alasan haid dan nifas. $^{10}$

Al-Thabâthabâ'îy"11 mengatakan bahwa yang dimaksud dengan "kaum lakilaki itu adalah pemimpin bagi kaum perempuan, oleh karena Allah telah melebihkan sebagian mereka (laki-laki) atas sebagian yang lain (perempuan), dan karena mereka (laki-laki) telah menafkahkan sebagian dari harta mereka" adalah keutamaan alamiah (thab') laki-laki atas perempuan, yaitu kelebihan dalam hal potensi reflektif (quwwat al-ta'aqqul) laki-laki, yang berarti keberanian, kekuatan dan kemampuan mengatasi kesulitan-kesulitan perbuatan dan sebagainya. ${ }^{12}$

Sedangkan kehidupan perempuan lebih sensitif dan emosional berdasarkan kelembutan dan kehalusan. dan yang dimaksud dengan mereka telah menafkahkan sebagian hartanya berarti mahar. Allâmah al-Thabathabâi menafsirkan ayat arrijâlu qawwâmuna ala nisâ', tidak terbatas pada kepemimpinan laki-laki. Menurutnya, kepemimpinan itu tidak menjadi hak monopoli laki-laki atas para isterinya, kecuali dalam hukum yang dibuat dari pihak laki-laki atas pihak perempuan dalam segi-segi yang umum yang dengannya berkaitan kedua belah pihak. ${ }^{13}$

\footnotetext{
${ }^{10}$ Ibid.

${ }^{11}$ Lihat al-Thabâthabâ'îy, Al-Mizân fî Tafsîr Alquran (Cet. I; Beirut: Muassasâ al-A'Imiy, 1991), h. 1. Al-Thabâthabâ'îy memperoleh pendidikan di kota kediamannya (Tibriz), hingga menguasai unsurunsur bahasa Arab dan ilmu-ilmu agama. Pada tahun 1365 H./1939 M. setelah ia hijrah ke Qum akibat Perang Dunia II, ia mulai mengajar dan berkonsentrasi pada bidang tafsir dan filsafat. Lihat, al-Thabâthabâ'îy, Alquran fî al-Islâm, diterjemahkan oleh Ilyas Hasan dengan judul Mengungkap Rahasia Alqur'an (Cet. XI; Bandung: Mizan, 1998), h. 5, al-Thabâthabâ'îy, Shi'te Islam, diterjemahkan oleh Djohan Effendi dengan judul Islam Syi'ah : Asal-Usul dan Perkembangannya (Cet. I; Jakarta: Pustaka Utama Grafiti, 1989), h. 22 dan al-Thabâthabâ'îy, Islamic Teachings: An Overview, diterjemahkan oleh Ahsin Muhammad dengan judul Inilah Islam: Upaya Memahami Seluruh Konsep Islam Secara Mudah (Cet. I; Jakarta: Pustaka Hidayah, 1989), h. 15.

${ }^{12}$ Sayyid Muhammad Husain al-Thabâthabâ'îy, Al-Mizân fí Tafsîr Alquran (Beirut:Mansyurâ Muassasâ al-'Alam li al-Mathbû'ât, 1993), h. 343.

${ }^{13}$ Ibid.
} 
Oleh karena itu, segi-segi yang bersifat umum dan sosial yang berkaitan dengan keutamaan laki-laki, seperti segi kepemimpinan negara (hukûmah) dan iman (qadhaâ'), yang diatasnya ditegakkan kehidupan sosial, hanya akan tegak dengan ta'aqqul yang secara alamiah lebih dimiliki oleh kaum laki-laki dibanding oleh kaum perempuan. Maka demikian juga, seperti pertahanan dan perang yang menuntut kekuatan fisik dan pemikiran, termasuk bagian kepemimpinan laki-laki.

Dengan kata lain, bahwa kepemimpinan (qawwâm) dari pihak laki-laki atas pihak perempuan dalam masyarakat pada dasarnya berkaitan dengan segi-segi umum bersama di antara keduanya, yang berkaitan dengan kelebihan reflektif lakilaki dan keberaniannya. Kesemuanya itu merupakan segi-segi kepemimpinan negara (hukûmah), kehakiman (qadhâ') dan perang, tanpa harus membatalkan kehendak individual perempuan dan amal pada dirinya. Misalnya, jika ia hendak melakukan sesuatu yang disenanginya, maka suami tidak berhak menghalanginya sedikitpun dalam hal bahwa sesuatu itu bukanlah hal yang dilarang oleh ajaranajaran agama Islam. ${ }^{14}$

Selanjutnya, al-Thabâthabâ'îy menjelaskan bahwa kepemimpinan laki-laki atas perempuan, bukanlah berarti bahwa perempuan kehilangan kemerdekaan dalam memelihara hak-hak pribadi dan sosial. Akan tetapi hal ini bermakna bahwa jika laki-laki itu menafkahkan hartanya kepada seorang perempuan dalam hal istimtâ' (memberikan kesenangan), maka perempuan itu menjadi wajib untuk mentaatinya dan memberikan segala hal yang berkaitan dengan istimtâ' dan mubâsyarah (pergaulan suami isteri) pada saat suami sedang berada di rumah. Serta menjaga kehormatan dirinya dan harta suaminya pada saat ia tidak berada di rumah.

Muhammad al-Shâdiqîy tidak banyak berbeda dengan para mufassir di atas dalam menafsirkan ayat tentang kepemimpinan laki-laki, bahwa kepemimpinan laki-laki atas perempuan tercakup dalam hal kemaslahatan mereka, mengawasi mereka (raqâbah) dan memelihara (hurâsah) mereka. Al-Shâdiqîy menulis bahwa laki-laki itu adalah penjaga perempuan dalam hal setiap tuntutan kehidupan. Sebab, para laki-laki lebih cerdas akalnya, lebih kuat tubuhnya dan lebih tajam

\footnotetext{
${ }^{14}$ Ibid., h. 344 .
} 
pemikirannya dibanding perempuan. ${ }^{15}$ Menurutnya, kepemimpinan laki-laki atas perempuan mengambil dua bentuk, yaitu kepemimpinan takwini (qawwâmiyah takwînîyah) dan kepemimpinan tasyri (qawwâmiyah tasyrî’îyah). Selanjutnya, ada satu hal yang menarik dan berbeda dengan hampir semua mufassir dari pandangan al-Shâdiqîy tentang perempuan. Beliau memiliki penafsiran khusus tentang ayat "Allah telah melebihkan sebagian mereka (laki-laki) atas sebagian yang lain (perempuan)”. Beliau menulis bahwa kepemimpinan (qawwamah) di sini bukanlah karena keutamaan (tafâdhul) laki-laki atas perempuan. ${ }^{16}$

Menurut al-Shâdiqîy, kemungkinan kepemilikan keutamaan oleh laki-laki yang tidak dimiliki oleh perempuan adalah dalam hal kekuatan fisikal laki-laki dan kelemahan fisikal perempuan serta kemuliaan perempuan dalam hal iffah. Oleh karena itu, laki-laki sebagaimana diutamakan dalam hal kecerdasan, keunggulan fisikal dan dalam keharusan memberikan nafkah keluarga, dibebani tugas untuk memelihara perempuan. Sebaliknya, perempuan juga diutamakan atas laki-laki dalam hal keperempuanan (unûtsah) yang tidak dimiliki oleh laki-laki. Menurutnya, pengutamaan laki-laki atas perempuan atau perempuan atas laki-laki, tidak lain hanyalah sebagai premis hikmah rabbaniyah seperti yang disebutkan dalam firman Allah QS. 16:71 dan QS. 43:32.

Mengenai kepemimpinan perempuan dalam rumah tangga dan masyarakat, Quraish Shihab mengatakan bahwa kepemimpinan dalam setiap unit merupakan hal yang mutlak, lebih-lebih bagi setiap keluarga, karena mereka selalu bersama serta merasa memiliki pasangan dan keluarga. Oleh karenanya, kepemimpinan dalam rumah tangga itu dibebankan kepada suami sebagaimana Qs. an-Nisâ' ayat 34. Namun perlu diperjelas bahwa kepemimpinan tersebut tidak secara mutlak, tetapi tidak lebih dari pembagian kerja antara satu dengan yang lainnya. Peranan seorang isteri dalam rumah tangga adalah untuk menjadikan rumah tangga itu sakan yakni "tempat yang menenangkan dan menenteramkan seluruh anggotanya". ${ }^{17}$

\footnotetext{
${ }^{15}$ Muhammad al-Shâdiqîy, Al-Furqân fî Tafsiî Al-Qur'ân, Jilid V dan VI (Beirut-Libanon: Dâr al-Turâts al-Islâmi li al-Thibâ'ah wa al-Nasyr wa al-Tûsi, t.th.), h. 36. Lihat pula dalam Abdi M. Soeherman, et. al. (ed.), Jurnal al-Hikmah, No. 16, Volume VII (Bandung: Yayasan Mutahhari, 1996), h. 12-13.

16 Ibid, h. 38.

${ }^{17}$ Ibid., h. 314.
} 


\section{Kepemimpinan Perempuan di Ruang Publik dalam Tafsir Al-Kasysyâf}

Adapun mengenai hadis, "Tidak beruntung suatu kaum yang menyerahkan urusan mereka kepada perempuan", -menurut Quraish Shihab- hadis ini tidak bersifat umum. Hadis ini ditujukan kepada masyarakat Persia ketika itu, bukan kepada semua masyarakat dan dalam semua urusan. Oleh karenanya, tidak ada larangan boleh tidaknya perempuan menjadi seorang pemimpin dalam masyarakat atau terjun dalam dunia politik, karena tidak ditemukan satu ketentuan agama pun yang dapat dipahami sebagai larangan keterlibatan perempuan dalam dunia publik dan politik.

Perbedaan penafsiran tersebut sangat dipengaruhi oleh situasi, kondisi sosial dan adat istiadat di mana mereka hidup. Oleh karenanya, perbedaanperbedaan pendapat tersebut hendaknya dijadikan sebagai acuan untuk lebih memahami posisi perempuan dalam hal keterlibatannya sebagai pemimpin, baik dalam rumah tangganya ataupun dalam lingkungan masyarakatnya.

\section{Kepemimpinan Perempuan pada Ruang Publik}

Dalam memahami isu kodrat perempuan sering terjadi kerancuan, bahkan seakan merupakan polemik berkepanjangan, baik dari kalangan kaum pria maupun perempuan sendiri, kaum intelektual apalagi kaum awam. Kodrat perempuan dijadikan alasan untuk mereduksi berbagai peran perempuan di dalam keluarga maupun masyarakat. Sementara kodrat itu sendiri sudah dianggap sebagai pemberian Yang Maha Pencipta. Pemahaman seperti ini perlu dipertanyakan, apakah hal itu memang sudah menjadi kreasi Tuhan atau hanya rekayasa masyarakat -khususnya kaum pria- karena merasa takut dan khawatir mendapat saingan? Atau beberapa pertanyaan lain yang mungkin akan muncul.

Akibat dari opini yang dibangun terhadap makna "kodrat perempuan", misalnya asal kejadian atau penciptaannya, akal atau kemampuan dan agamanya yang kurang, menempatkan perempuan pada posisi yang rendah dan bahkan sangat lemah. Melalui lembaran sejarah dapat disaksikan betapa fatwa hakim agama Mekah berpengaruh dalam membangun opini masyarakat terhadap kedudukan perempuan. Ketika empat orang sultânah ${ }^{18}$ yang pernah memerintah

\footnotetext{
18Empat orang sultanah tersebut adalah Sultânah Tadj al-Alam (1641-1675), Nur al-Alam (16751678), Inâyat Syâh (1678-1688) dan Kamâlat Syâh. Lihat, Fatima Mernissi dan Riffat Hassan, Setara
} 
secara berkesinambungan, harus berakhir dan terputus karena fatwa hakim yang tidak membolehkan perempuan menjadi pemimpin negara dengan alasan telah menyalahi kodratnya sebagai perempuan. Demikian pula ketika melirik sejarah pergerakan nasional di Indonesia, partisipasi kaum perempuan secara kuantitatif dan kualitatif sangat kurang dibanding kaum pria. Salah satu sebabnya ialah adanya hambatan keagamaan. Sudah terlanjur dipersepsikan bahwa perjuangan fisik dan tugas-tugas politik adalah tugas kaum pria, sementara kaum perempuan hanya mengurus rumah tangga. Padahal keterlibatan kaum perempuan di dunia publik pada masa Nabi Muhammad Saw. demikian besar. ${ }^{19}$

Para mufassir yang tidak sependapat perempuan menjadi seorang pemimpin dalam dunia publik, mendasarkan pandangannya tersebut pada hadis Nabi Saw. yang berbunyi :

$$
\begin{aligned}
& \text { حدثنا عثمان بن الهيثم حدثنا عوف بن الحسن, هن ابي بكرة قال : لقد نفعني الله بكلمة سهعتها من رسول الله }
\end{aligned}
$$

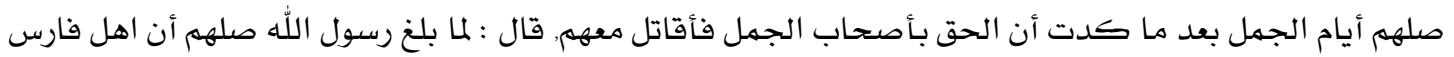

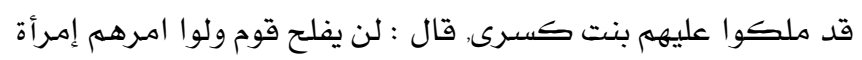

"Usman bin al-Haitsam menceriterakan kepada kami, dari Auf bin al-Hasan dari Abi Bakrah berkata : "Sesungguhnya Allah telah memberikan hikmah kepadaku pada saat perang Jamal dengan suatu kalimat yang saya dengar dari Rasulullah saw. setelah aku hampir mengikuti pasukan unta. ketika kusampaikan kepada Rasulullah Saw. bahwa kerajaan Persia dipimpin oleh anak perempuannya, maka Nabi Saw. bersabda : "Tidak akan berbahagia (sukses) suatu kaum (masyarakat) yang menyerahkan (untuk memimpin) urusan mereka kepada perempuan". 20

di Hadapan Allah: Relasi Laki-laki dan Perempuan dalam Tradisi Islam Pasca Patriarki, terj. Tim LSPPA (Yogyakarta: LSPPA, 1995), h. 208.

${ }^{19}$ Keterlibatan para perempuan pada masa Rasulullah Saw. dapat dilihat antara lain : Ummu Hani yang dibenarkan sikapnya oleh Rasulullah Saw. ketika memberi jaminan keamanan kepada sementara orang musyrik, Aisyah isteri Nabi Saw. sendiri memimpin peperangan melawan Ali ibn Abi Thalib ra. yang ketika itu menduduki jabatan kepala negara, Ummu Salamah (isteri Nabi), Shafiyah, Laila al-Ghaffariyah, Ummu Sinan al-Islamiyah dan lain-lain juga tercatat sebagai tokohtokoh yang terlibat peperangan. Dalam bidang perdagangan, isteri Nabi Saw. Khadijah binti Khuwailid tercatat sebagai seorang saudagar yang sangat sukses, Zainab binti Jahsy (isteri Nabi Saw) yang aktif bekerja sampai pada menyamak kulit binatang, al-Syifa' seorang perempuan yang pandai menulis, ditugaskan oleh khalifah Umar ra. sebagai petugas yang menangani pasar kota Madinah, dan beberapa contoh lain keterlibatan perempuan dalam masyarakat. Lihat, M. Quraish Shihab, Membumikan Alquran: Fungsi dan Peran Wahyu dalam Kehidupan Masyarakat (Cet. XI; Bandung: Mizan, 1995), h. 274-276.

${ }^{20}$ Abû Abdullah Muhammad bin Ismâil bin Ibrâhim al-Bukhâri, Juz V, ibid., h. 160 dan Juz VIII, h. 434. Dalam sanad yang lain tetapi matannya sama dapat dilihat pada Abû Isa Muhammad bin Isa ibn Sawrah at-Turmudzîy, Sunan at-Turmudzîy, Juz IV (Beirut: Dâr al-Kutub al-'Ilmiyah, t. th.), h. 34 dan Abû Abdur Rahman bin Syu'aib an-Nasâ'îy, Sunan an-Nasâ'îy, Juz IV (Mesir: Musthâfa al-Bâby al-Halabîy wa Awlâduh, 1964), h. 227. 
Hadis yang mengatakan bahwa perempuan kurang akal dan kurang agamanya, yaitu :

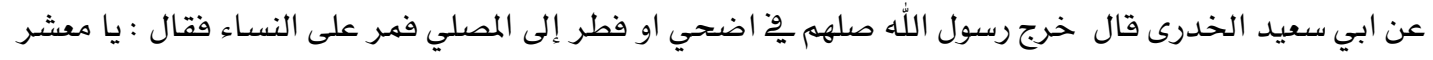

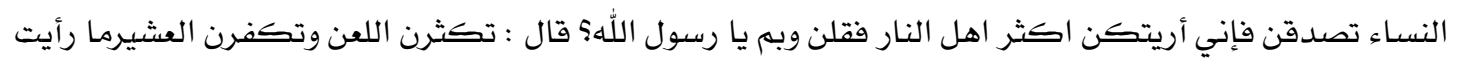

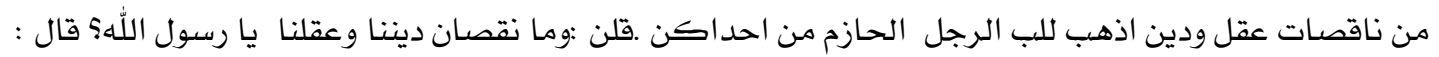

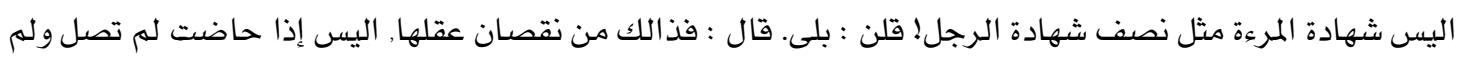

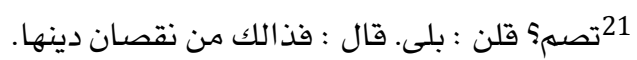

"Diriwayatkan oleh Abi Sa'id al-Khudriy, ia berkata bahwa Rasulullah Saw. berangkat ke tempat shalat pada hari raya Adha dan hari raya fitri. Ketika berjumpa dengan para perempuan, beliau bersabda : "Hai para perempuan, bersedekahlah kalian, sebab saya lihat kalian paling banyak penghuni neraka". Kemudian para perempuan bertanya: "Mengapa ya Rasul?". Rasul menjawab, "Kalian banyak mengucapkan kutukan dan mengingkari kebaikan suami. Aku tidak pernah melihat perempuan-perempuan yang kurang akal dan agamanya dapat meluluhkan hati pria yang kokoh perkasa dari salah seorang di antara kalian". Mereka bertanya, "Di mana letak kekurangan akal dan agama kami, ya Rasul?". Beliau menjawab, "Bukankah kesaksian seorang perempuan setara dengan separuh kesaksian pria?”. Mereka berkata, "Betul”. Rasulullah bersabda, "Itulah kekurangan akalnya. Bukankah bila perempuan sedang haid tidak shalat dan tidak puasa?". Mereka berkata : "Betul". Rasulullah Saw. bersabda : "Begitulah kekurangan agamamu".

Kedua hadis inilah yang menjadi rujukan para mufasir yang tidak menginginkan perempuan untuk berkiprah di dunia publik.Dalam budaya yang ada di Indonesia, umumnya perempuan mempunyai peran ganda. Ironisnya, kaum perempuan menerimanya tanpa tawar menawar. Dibalik kodrat yang diembannya, ia tetap tidak dapat meninggalkan peran domestiknya. Urusan keluarga, urusan rumah tangga atau sering diistilahkan ruang lingkup domestik pada umumnya diserahkan kepada kaum perempuan, sehingga oleh perempuan hal-hal tersebut pada gilirannya selalu dijadikan nomor satu. ${ }^{22}$

Peran dan kedudukan perempuan sering dikotakkan dalam peran tertentu, misalnya ibu rumah tangga. Kuatnya peran seorang perempuan dengan tugas pertama dan utama di sektor domestik, membuat orang percaya sepenuhnya bahwa itulah memang garis takdir perempuan atau kodrat perempuan yang telah diciptakan dan ditentukan Tuhan. Peran dan kedudukannya menjadi ibu rumah

\footnotetext{
${ }^{21}$ Abû Abdullah Muhammad bin Ismâil bin Ibrâhim al-Bukhari, Shahih al-Bukhari, Juz I, h. 78.

${ }^{22} \mathrm{Hj}$. Zaitunah Subhan, Tafsir Kebencian, h. 64.
} 
tangga terkesan mutlak, semutlak ia memiliki rahim atau seabsolut pria memiliki sperma untuk pembuahan. ${ }^{23}$

Padahal, di samping memainkan peran sebagai isteri pendamping suami, ibu rumah tangga dan pendidik bagi anak-anaknya, seorang perempuan dapat menikmati haknya untuk memainkan peranan lain di luar keluarga sesuai dengan kodratnya. Hal ini karena masyarakat, seperti halnya keluarga, merupakan unit hubungan yang sangat penting dalam dunia Islam. Karena terdapat suatu ikatan yang erat antara individu dan anggota keluarganya yang lain, maka terdapat suatu mata rantai yang kuat antara individu dan orang lain dalam suatu masyarakat. ${ }^{24}$

Mengenai larangan keterlibatan kaum perempuan di luar rumah tangganya, para mufassir sering merujuk kepada Qs. al-Ahzâb ayat 33 :

$$
\text { لـوقرن بِّ بيوتكن ولا تبرجن تبرج الجاهلية الأولي ... }
$$

"Dan hendaklah kamu tetap di rumahmu dan janganlah kamu berhias dan bertingkah laku seperti orang-orang jahiliyah yang dahulu ...".

Mengenai tafsiran ayat tersebut, az-Zamakhsyarîy tidak menjelaskan apa yang dimaksud dengan وقرن فِّ بيوتكن, tetapi hanya menjelaskan kedudukan kalimat tersebut dalam kaedah bahasa Arab. Misalnya, dikatakan bahwa kata قرن dikasrah huruf kafnya, berasal dari قر - يقر- وقارا atau قرا . Selanjutnya az-Zamakhsyarîy menafsirkan apa yang dimaksud dengan kata الجاهلية الأولى. Dikatakan bahwa الجاهلية adalah masa yang telah lampau, yang disebut sebagai masa kebodohan dari

\footnotetext{
${ }^{23}$ Ibid., h. 65.

${ }^{24}$ Harun Nasution dan Bahtiar Effendi, Hak Azasi Manusia Dalam Islam (Cet. I; Jakarta: Yayasan Obor Indonesia, 1987), h. 1987. Dalam hal ini Mahmud Syaltut, mantan Syekh al-Azhar menulis dalam bukunya Min Tawjihat al-Islam, bahwa :

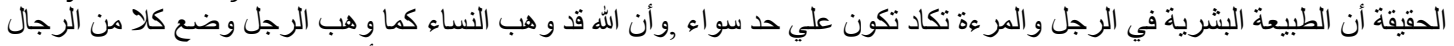

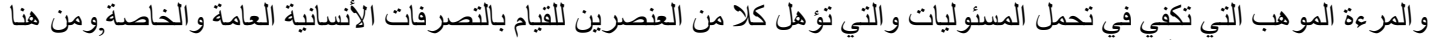

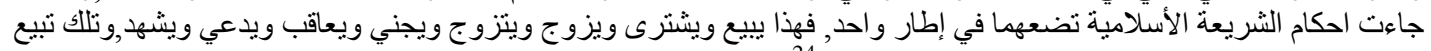

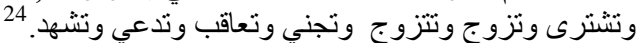

"Tabi'at kemanusiaan antara lelaki dan perempuan hampir dapat (dikatakan) sama. Allah Swt. telah menganugerahkan kepada perempuan -sebagaimana menganugerahkan kepada lelaki- potensi dan kemampuan yang cukup untuk memikul tanggung jawab, dan menjadikan kedua jenis kelamin ini dapat melaksanakan aktifitas-aktifitas yang bersifat umum maupun khusus. Karena itu, hukumhukum syari'at pun meletakkan keduanya dalam satu kerangka. Yang ini (lelaki) menjual dan membeli, mengawinkan dan kawin, melanggar dan dihukum, menuntut dan menyaksikan, dan yang itu (perempuan) juga demikian, dapat menjual dan membeli, mengawinkan dan kawin, melanggar dan dihukum serta menuntut dan menyaksikan". Lihat, Mahmud Syaltut, Min Tawjihât al-Islâm (Kairo: al-Idârat al-'Ammah li al-Azhâr, 1959), h. 193.
} 
orang-orang yang bodoh. Masa tersebut yaitu masa di mana nabi Ibrahim as. dilahirkan dan masa antara Adam dan Nuh as. Suatu pendapat mengatakan bahwa, masa jahiliyah yang pertama yaitu masa antara nabi Idris dan Nuh as. Adapula yang mengatakan, masa antara nabi Daud dan Sulaiman as. Dan masa jahiliyah terakhir adalah masa antara nabi Isa dengan Muhammad saw.. Namun dapat pula dikatakan bahwa الجاهلية الأولى adalah kekufuran sebelum datangnya Islam, dan adalah kefasikan dan kebanggaan dalam Islam. Maka ungkapan lafal ini seakan-akan memberi makna janganlah mereka para perempuan berbicara dengan memakai perhiasan jahiliyah dalam Islam dengan menyerupai orang-orang jahiliyah yang kufur. ${ }^{25}$

Az-Zamakhsyarîy menafsirkan ayat tersebut dengan tidak menjelaskan sejauh mana bolehnya keterlibatan kaum perempuan di luar rumah, seperti yang sering dipaparkan oleh mufassir lainnya. Namun, terlepas dari penafsiran azZamakhsyarîy tersebut di atas, contoh-contoh keterlibatan kaum perempuan dalam masyarakat pada masa Rasulullah Saw. patut dijadikan sebagai acuan hukum. Yang menjadi persoalan berikutnya adalah bagaimana pandangan azZamakhsyarîy mengenai kepemimpinan perempuan dalam masyarakat di bidangbidang penting, seperti sebagai kepala negara, hakim dan sebagainya?.

Berdasar pada penafsiran az-Zamakhsyarîy mengenai kepemimpinan lakilaki dalam Qs. an-Nisâ': 1 dan 34, maka dapat disimpulkan bahwa az-Zamakhsyarîy tidak sependapat apabila jabatan kepala negara, hakim dan beberapa jabatan vital lainnya dijabat oleh seorang perempuan. Hal ini penulis analisis dari penafsirannya bahwa laki-laki mempunyai kelebihan dibanding kaum perempuan, seperti kelebihan intelektual (akal), lebih tegas, tekadnya lebih kuat, lebih berani dan kekuatan fisik yang lebih besar. Sementara dalam melaksanakan tugas-tugas yang diembannya selaku hakim, kepala negara dan jabatan vital lainnya, beberapa hal yang diungkapkan sebagai kelebihan laki-laki tersebut sangat dibutuhkan. Tanpa kemampuan-kemampuan tersebut, maka sangat mustahil seorang perempuan mampu menjalankan amanat yang diemban di pundaknya. Oleh karenanya, tanpa menelusuri lebih jauh pendapat az-Zamakhsyarîy mengenai

${ }^{25}$ Az-Zamakhsyarîy, Tafsîr al-Kasysyâf, Juz III, h. 521. 
kepemimpinan perempuan dalam sektor publik, sudah dapat dipahami bahwa dalam pandangannya, seorang perempuan tidak layak menduduki posisi-posisi kekuasaan publik dan politik, terlebih lagi sebagai pemimpin negara.

\section{Analisis Tafsir az-Zamakhsyarîy tentang Kepemimpinan Perempuan}

Uraian sebelumnya mengemukakan tentang pandangan az-Zamakhsyarîy mengenai ayat-ayat yang dijadikan rujukan oleh para ulama dalam mengungkap kepemimpinan perempuan dalam berbagai bidang. Dengan menggunakan argumen kebahasaan, az-Zamakhsyarîy menyimpulkan bahwa Hawa -sebagai perempuan pertama- diciptakan dari tulang rusuk Adam. Pandangan ini kemungkinan juga dilatar belakangi oleh hadis yang diperpegangi oleh ulama pada masanya yaitu hadis tentang penciptaan perempuan dari tulang rusuk Adam yang paling bengkok.

Pemahaman az-Zamakhsyarîy yang seakan melecehkan keberadaan perempuan itu berangkat dari penafsiran awalnya mengenai Qs. an-Nisa ayat 1, خلقكم من نفس واحدة/خلق لكم من نقس واحدة bahwa yang dimaksud dengan kalimat adalah bahwa manusia diciptakan dari jiwa yang satu yakni jiwa/diri Adam. Hal ini dimaknainya bahwa Hawa sebagai perempuan pertama berasal dari diri Adam. Penafsiran ini berindikasi kurang menguntungkan kaum perempuan, karena menimbulkan imej yang buruk dalam masyarakat. Pandangan negatif bahwa kedudukan kaum Adam lebih tinggi dari kaum Hawa berawal dari penafsiran ayat ini. Di samping itu, az-Zamakhsyarîy tidak menjelaskan lebih jauh dan gamblang dasar hukum yang dipergunakan sehingga menafsirkan kalimat نقس واحدة dengan diri Adam. Padahal dari segi bahasa kata نقس bersifat netral, bisa berlaku bagi pria dan juga bagi perempuan.

Dalam menganalisis penafsiran az-Zamakhsyarîy mengenai Qs. an-Nisa ayat 1, Muhammad Abduh dan Rasyîd Ri«â juga memberikan komentar bahwa tidak dapat dipastikan kata نقس واحدة berarti Adam, kecuali bagi yang meyakini bahwa semua manusia adalah berasal dari anak cucu Adam. Tetapi bagi yang meyakini bahwa setiap ras punya asal-usul sendiri, maka yang dimaksud dengan Adalah nenek moyang mereka masing-masing. Menurutnya, kata رجال نقس واحدة dan 
وبث منهما رجالا كثيرا ونساء dalam bentuk nakirah menandakan bahwa kalimat نساء menunjukkan ketidakpastian. Kalau memang yang dimaksud dengan Adam (ma'rifah), seharusnya kedua kata itu diungkapkan dalam bentuk ma'rifah juga. Misalnya, وبث منهما جميع الرجال والنساء. Karena khitab pada ayat ini bersifat umum, نقس واحدة yaitu seluruh umat manusia, bagaimana mungkin yang dimaksud dengan adalah person tertentu, yaitu Adam, padahal tidak semua manusia mengenal Adam (dan Hawa), bahkan mendengarnya pun tidak pernah. ${ }^{26}$

Menurut Ridâ, mayoritas mufassir termasuk -az-Zamakhsyarîy- menafsirkan bahwa نقس واحدة adalah Adam bukan berdasarkan teks ayat, tetapi berdasarkan keyakinan yang sudah diterima secara umum pada waktu itu bahwa Adam adalah nenek moyang umat manusia. Menurutnya, teks ayat menegaskan bahwa secara esensi, semua manusia mempunyai asal kemanusiaan yang sama. Oleh sebab itu, semuanya bersaudara, tanpa memandang warna kulit, perbedaan bahasa atau keyakinan tentang asal usul manusia itu sendiri. Jadi, ayat ini tidak bermaksud menjelaskan asal kejadian manusia. ${ }^{27}$

Di sisi lain, tampaknya az-Zamakhsyarîy terpengaruh kepada hadis yang mengatakan bahwa perempuan diciptakan dari tulang rusuk Adam. Hal ini berarti bahwa az-Zamakhsyarîy lebih mendahulukan teks hadis daripada Alquran itu sendiri. Sebab Alquran tidak pernah menjelaskan secara qath'i (ekplisit) bahwa isteri Adam (Hawa) diciptakan dari tulang rusuknya. Alquran hanya berkata, Tuhan menciptakan darinya isterinya. Allah tidak menyebut tulang rusuk dan tidak pula menjelaskan bahwa kata nafs wâhidah itu ditujukan kepada diri Adam.

\footnotetext{
${ }^{26}$ Sayyid Muhammad Rasyîd Ridâ, Tafsîr Alquran al-Hakîm (Tafsîr al-Manâr), Jilid IV (Cet. III; Beirut: Dâr al-Fikr, 1973), h. 324. Ungkapan Muhammad Abduh bahwa tidak semua manusia mengenal Adam (dan Hawa) bahkan mendengarnya pun tidak pernah, dibantah oleh Yunahar Ilyas dengan mengemukakan bahwa informasi tentang asal-usul umat manusia diberitakan oleh Alquran, maka melalui penalaran secara utuh terhadap Alquran, setiap orang akan dapat mengetahui dan mengenal Adam sebagai manusia pertama yang menjadi asal seluruh umat manusia. Menurutnya, ketidaktahuan umum karena tidak membaca Alquran tidak dapat dijadikan sebagai alasan penolakan terhadap informasi tersebut. Jika benar seperti apa yang dikatakan Muhammad Abduh, maka tentu banyak informasi lain dalam Alquran yang akan ditolak dengan alasan tidak semua orang mengetahuinya. Lihat, H. Yunahar Ilyas, Feminisme Dalam Kajian Tafsir Alquran: Klasik dan Kontemporer (Cet. I; Yogyakarta: Pustaka Pelajar, 1997), h. 107.
}

${ }^{27}$ Ibid. 
Dalam menafsirkan Qs. an-Nisâ': 32 dan an-Nahl: 97, az-Zamakhsyarîy mengakui adanya kesamaan hak pria dan perempuan dalam memperoleh hasil usahanya. Namun, dalam hal kepemimpinan dalam rumah tangga, sebagaimana Qs. an-Nisâ' : 34 az-Zamakhsyarîy lebih cenderung menempatkan posisi kaum perempuan di bawah kaum pria. Hal ini tampak pada ungkapannya ketika menafsirkan kata بها فضل الله بعض bله bahwa kepemimpinan dalam rumah tangga itu diberikan oleh Allah kepada pria karena kelebihannya dalam beberapa hal. Dari kelebihan-kelebihan yang dipaparkannya, kelihatan bahwa azZamakhsyarîy menganggap kaum pria itu mempunyai banyak keunggulan ketimbang perempuan.

Di sisi lain, az-Zamakhsyarîy tidak melihat bahwa kepemimpinan laki-laki (suami) dalam rumah tangganya tidak dapat berjalan sebagaimana mestinya tanpa ditunjang oleh kemampuan perempuan (isteri) dalam menangani hal-hal yang mungkin saja laki-laki sulit untuk berkonsentrasi melakukannya, misalnya dalam hal mengurusi anak-anak. Kelembutan, kasih sayang dan ketelatenan seorang perempuan dalam mendidik anak-anaknya adalah sebuah tanggung jawab yang tidak begitu diperhatikan oleh az-Zamakhsyarîy. Hal ini berarti bahwa dalam mengurus rumah tangga secara langsung, kaum perempuan juga adalah seorang pemimpin yang harus diakui kapabilitasnya.

Alquran tidak secara tegas menjelaskan apa yang menjadi keunggulan pria atas perempuan, sehingga penafsiran yang diberikan oleh para mufassir pun menjadi beragam dan kontroversial. Kelebihan-kelebihan yang dikemukakan oleh para mufassir -termasuk az-Zamakhsyarîy- pada intinya berkisar pada keunggulan laki-laki dari segi fisik, intelektual dan agama.

Sebagaimana telah dikemukakan sebelumnya, bahwa tampak azZamakhsyarîy memperluas pembicaraan mengenai keunggulan kaum pria sebagai jenis kelamin, bukan dalam konteks suami, sebagaimana yang diinginkan oleh ayat .الرجال قوامون علي النساء بها فضل الله بعضهم علي بعض Sehingga kelebihan-kelebihan yang diberikan itu tidak relevan dengan fungsi dan tugas utama pria sebagai seorang pemimpin dalam rumah tangganya. Misalnya, disebutkan kelebihan fisik laki-laki; kuat, punya jenggot bahkan disebutkan juga memakai sorban sebagai suatu 
kelebihan. Demikian juga tugas dan peran laki-laki dalam upacara-upacara keagamaan, seperti laki-laki menjadi muadzin, khatib, imam dan sebagainya. Apabila pemahaman az-Zamakhsyarîy tersebut diterima sebagai suatu kelebihan laki-laki, maka dapat dikatakan bahwa kelebihan perempuan juga antara lain, perempuan haid, hamil, melahirkan, menyusui, cantik, lembut dan lain sebagainya. Namun, perbedaan-perbedaan tersebut harus dipahami tidak lebih dari sebuah pembagian tugas, bukan sebagai suatu kelebihan.

Mengenai kelebihan pria dari segi intelektual -sebagaimana penafsiran azZamakhsyarîy, penulis melihatnya bukan sebagai potensi intelektual yang dimiliki, tetapi apabila terjadi perbenturan antara nalar dan rasa, maka laki-laki lebih mendahulukan nalar daripada rasanya. Sebaliknya perempuan lebih mendahulukan rasa daripada nalarnya. Namun, statement ini tidak berlaku untuk segala situasi dan kondisi, sebab dalam kondisi tertentu mungkin akan terjadi sebaliknya. Hal ini berarti bahwa pria dan perempuan dapat melakukan persaingan secara sehat untuk mengembangkan diri lebih jauh. Bahkan dapat saja terjadi kemampuan intelektual perempuan lebih tinggi ketimbang laki-laki, dan hal ini sangat dipengaruhi oleh lingkungan pendidikan dan lingkungan masyarakat yang membentuknya.

Kepemimpinan laki-laki dalam rumah tangga dari segi normativitas adalah memberikan kepastian siapa yang menjadi pemimpin di antara keduanya (suami atau isteri), sehingga tertutup peluang timbulnya perselisihan. Namun di sisi lain, kelemahannya adalah ketika persoalan tersebut diperhadapkan pada sebuah realitas, yakni tatkala secara faktual suami tidak memenuhi persyaratan untuk menjadi pemimpin, baik yang bersifat integritas pribadi, maupun kemampuan finansial yang disyaratkan oleh Alquran secara eksplisit. Hal ini tidak dijelaskan oleh az-Zamakhsyarîy dalam menafsirkan kata qawwâmun pada ayat tersebut.

Analisis lain yang penulis dapat kemukakan mengenai penafsiran azZamakhsyarîy terhadap ayat-ayat kepemimpinan perempuan adalah bahwa azZamakhsyarîy dalam mengupas ayat-ayat kepemimpinan perempuan, tidak begitu jauh menjelaskan konsep dasarnya mengenai kepemimpinan perempuan itu sendiri. 
Hal ini mungkin dilatarbelakangi oleh situasi dan kondisi kehidupan azZamakhsyarîy. Sebagaimana dipaparkan dalam pembahasan sebelumnya bahwa az-Zamakhsyarîy adalah seorang bujangan yang sangat tidak memperhatikan perempuan. Kurangnya perhatian az-Zamakhsyarîy terhadap perempuan dapat disebabkan oleh kefakirannya, ketidakstabilan hidupnya karena keadaan materi yang dimilikinya dan penyakit jasmani yang dideritanya. Cacat kakinya merupakan salah satu sebab yang menjadikan ia merasa lemah dan tidak sanggup untuk menanggung perkawinan dan tanggung jawab keluarga. Ini juga mungkin merupakan penyebab menjauhnya para perempuan dari diri az-Zamakhsyarîy. Kemungkinan lain yang menjadi penyebabnya adalah karena kesibukannya menuntut ilmu dan kecintaannya terhadap ilmu dan karya-karya yang ditulisnya menyebabkan ia menjauh dari persoalan perkawinan. ${ }^{28}$ Namun yang pasti bahwa az-Zamakhsyarîy memang tidak menyukai perempuan, bahkan menghindarinya. Hal ini disebabkan oleh karena az-Zamakhsyarîy tidak ingin menanggung resiko dari sebuah pernikahan tersebut. Sebagaimana penulis simpulkan dari ungkapan syairnya, yang berbunyi :

$$
\text { 口ـاسعد الناس ناس قط ما ولدوا \# ولا غدوالخراب الأرض عمارا }
$$

Orang yang paling bahagia adalah orang yang tidak beranak;

dan orang yang tidak mempunyai rumah;

Sehingga mereka tidak akan meratapi anak-anaknya jika mereka mati; dan mereka juga tidak akan terkejut, jika rumah mereka roboh.

Namun demikian, sebuah ungkapan berupa nasehat yang diberikan oleh az-

Zamakhsyarîy mengenai perempuan dan patut untuk direnungkan adalah :

$$
\text { لاتخطب المررة لحسنها ولكن لحصنها, فإن اجتمع الحصن والجمال فذاك هو الكمال وأكملهن ذالك أن تعيش }
$$

$$
\text { 口صصورا وإن عمرت عصورا. }
$$

“Janganlah engkau meminang perempuan karena kecantikannya, tetapi karena keturunannya, apabila telah berkumpul keturunan dan kecantikannya maka

\footnotetext{
${ }^{28}$ Lihat, Abdul Majid Dhayyâb, Ibid., h. 17-18.

${ }^{29}$ Sebagaimana dikutip oleh Thib Raya dari Abd. Majid Dhayyâb, Muqaddimah al-Tahqîq, dalam Rabi' al-Abrâr oleh az-Zamakhsyarîy (Mesir: Dâr al-Hai'ah al-Mishriyyah li al-Kuttâb, 1992), h. 17. Lihat pula, Syekh Kâmil Muhammad Muhammad 'Audhah, op. cit., h. 57.
} 
itulah sebuah kesempurnaan dan kesempurnaannya itulah yang akan menyibukkan"

Terlepas dari uraian di atas, az-Zamakhsyarîy dalam menafsirkan ayat-ayat kepemimpinan lebih banyak menganalisis dari segi kaedah kebahasaan, sehingga yang sangat menonjol adalah tinjauan kebahasaannya. Hal ini -menurut analisis penulis- adalah merupakan keistimewaan az-Zamakhsyarîy dalam menafsirkan Alquran, tetapi dapat pula menjadi sebuah kelemahan. Alasannya adalah dengan tinjauan kebahasaan semata, maka penafsiran ayat yang diinginkan tidak begitu nampak, hanya berbentuk sebuah penjelasan kaedah bahasa. Namun, hal itupun tidak dapat dipersalahkan sepenuhnya kepada az-Zamakhsyarîy, sebab kecenderungan az-Zamakhsyarîy dalam menafsirkan ayat-ayat Alquran dari segi bahasa sesuai dengan kebutuhan masyarakat pada masanya.

\section{E. Kesimpulan}

Pandangan al-Zamakhsyari terhadap kepemimpinan perempuan cenderung bersifat normatif, yaitu memberikan peluang perempuan menjadi pemimpin, sehingga tertutup peluang timbulnya perselisihan. Namun pada az-Zamakhsyarîy lebih cenderung menempatkan posisi kaum perempuan di bawah kaum pria. Hal ini tampak pada ungkapannya ketika menafsirkan kata بها فضل الله بعض علي bahwa kepemimpinan dalam rumah tangga itu diberikan oleh Allah kepada pria karena kelebihannya dalam beberapa hal, bahkan az-Zamakhsyarîy menganggap kaum pria mempunyai banyak keunggulan ketimbang perempuan, walau pernyataan tersebut tidak diurai oleh az-Zamakhsyarîy secara detail. 


\section{Daftar Pustaka}

Al-Quran al-Karim

Abduh, Muhamad, Tafsîr al-Manâr, Jilid I, Mesir: al-Haiah li al-Mishriyah, t.t.

Abdul Hasan, al-Ghaffar Abdur Rasul. Al-Mar'ah al-Mua'shirah. Diterjemahkan oleh Baharuddin Fanani dengan judul Wanita Islam dan Gaya hidup Modern. Cet. III; Bandung: Pustaka Hidayah, 1996.

Abd. al-Baqy, Muhammad Fu'ad. Al-Mu'jam al-Mufahharas li Alfadz Alquran. Beirut: Dar al-Fikr, 1987.

Al-Aqqad, Mahmud Abbas. Al-Mar'ah fi Al-Quran. Diterjemahkan oleh Chadijah Nasution dengan judul Wanita Dalam Alquran. Jakarta: Bulan Bintang, 1984.

Ahmad Dahri, Ibnu. Peran Ganda Wanita Indonesia. Jakarta: al-Kautsra, 1993.

Aridl, Ali Hasan. Tarikh 'Ilm al-Tafsir wa Manahij al-Mufassirin, diterjemahkan oleh Ahmad Akrom dengan judul Sejarah dan Metodologi Tafsir. Cet. II; Jakarta: PT. Raja Grafindo Persada, 1994.

Bâqi, Muhammad Fu'âd Abdul, Mu'jam al-Mufahras li Alfâd Alquran, Beirut: Dâr alFikr, 1991.

Baried, S. Baroroh, Konsep Perempuan Dalam Islam, dalam Lies M. Marcos dan Johan Hendrik Meuleman

Dhayyâb, Abd. Majid, Muqaddimah al-Tahqîq, dalam Rabi' al-Abrâr oleh azZamakhsyarîy, Mesir: Dâr al-Hai'ah al-Mishriyyah li al-Kuttâb, 1992

Analisis Gender dan Transformasi Sosial. Cet. I; Yogjakarta: Pustaka Pelajar, 1993.

Al-Faraqi, Lamya'. Woman, Muslim Society and Islam. Diterjemahkan oleh Mansyur Abadi dengan judul 'Ailah, Masa Depan Wanita. Cet. I; Surabaya: Pustaka Progressif, 1997.

Al-Farmawiy, Abd. Hayy. Al-Bidayat fi al-Tafsir al-Maudhu'iy diterjemahkan oleh Suryan A. Jamrah dengan judul Metode Tafsir Maudhu'iy. Cet. I; Jakarta: LSIK dan PT. Raja Grafindo Persada, 1994.

Fakih, Mansour, et. al. Membincang Feminisme: Diskursus Gender Perspektif Islam. Cet. I; Surabaya: Risalah Gusti, 1996.

Fawdah, Mahmud Basuni. Altafsir wa Manahijuhu diterjemahkan oleh Moechtar Zoerni dan Abd. Kadir Hamid dengan judul Tafisr-tafsir Alquran; Perkenalan dengan Metodologi Tafsir. Cet. I; Bandung: Pustaka, 1987.

Ibrahim, Sulaiman, Hukum Domestikasi dan Kepemimpinan Perempuan dalam Keluarga, Jurnal al-Ulum, Vol. 13, No. 2, 2013.

Ibrahim, Sulaiman, I'jāz Al-Qur'ān: Menelusuri Bukti Keotentikan Al-Qur'an, Farabi, Vol. Volume 12 Nomor 1 Juni 2015. 
Ja'far, Muhammad Anis Qasim, Kekuasaan Menelusuri Hak Politik dan Persoalan Gender dalam Islam, terj. Irwan Kurniawan dan Abu Muhammad, Bandung: Zaman Wacana Mulia, 1998.

al-Khuliy, Amin, Kasysyâf az-Zamakhsyarîy, Mesir: Maktabah al-Usrah, t.th.,

Al-Khauly, Bahay. Islam dan Persoalan Wanita Modern. Solo: Ramadhani, 1988.

Mas'adi, Masdar F., Perempuan di antara Lembaran Kitab Kuning, dalam Lies M. Marcos dan Johan Hendrik Meuleman, Perempuan Islam Indonesia: Dalam Kajian Tekstual dan Kontekstual, Jakarta: INIS, 1993.

Muthahhari, Murtadha. Wanita dan Hak-haknya Dalam Islam. Penerjemah M. Hashem. Bandung: Pustaka Salman ITB, 1986.

Setiawan, H. M. Nur Kholis, Tafsir Sebagai Resepsi al-Qur'an; Ke Arah Pemahaman Kitab Suci dalam Konteks Keindonesiaan. http://digilib.stital.ac.id/repository/tafsir-keindonesiaan_kholis.pdf. Diakses pada 15 Desember 2018.

al-Shâdiqîy, Muhammad, Al-Furqân fî Tafsiî Al-Qur'ân, Jilid V dan VI, BeirutLibanon: Dâr al-Turâts al-Islâmi li al-Thibâ'ah wa al-Nasyr wa al-Tûsi, t.th.

Salim, Abdul Muin. Fiqhi Siyasah: Konsepsi Kekuasaan Politik Dalam Alquran. Cet. I; Jakarta: PT. Raja Grafindo Persada, 1995.

As-Siba'iy, Mustafa. Wanita di antara Hukum dan Perundang-undangan, judul asli Al-Mar'ah Bainal Fiqh wal Qanun. Jakarta: Bulan Bintang, 1966.

Shihab, M. Quraish. Membumikan Alquran: Fungsi dan Peran Wahyu Dalam Kehidupan Masyarakat. Cet. XI; Bandung: Mizan, 1995.

Shihab, M. Quraish. Wawasan Alquran: Tafsir Mauhu'iy atas Pelbagai Persoalan Umat.. Cet. III; Bandung: Mizan, 1996.

Syaltut, Mahmud. Alquran wal Mar'ah. Kairo: Dar al-Thaba'ah, 1960.

Syaltut, Mahmud, Min Tawjihât al-Islâm, Kairo: al-Idârat al-'Ammah li al-Azhâr, 1959.

Ridhâ, Sayyid Muhammad Rasyîd, Tafsîr Alquran al-Hakîm (Tafsîr al-Manâr), Jilid IV, Cet. III; Beirut: Dâr al-Fikr, 1973.

al-Thabâthabâ'îy, Alquran fî al-Islâm, diterjemahkan oleh Ilyas Hasan dengan judul Mengungkap Rahasia Alqur'an, Cet. XI; Bandung: Mizan, 1998.

al-Thabâthabâ'îy, Shi'te Islam, diterjemahkan oleh Djohan Effendi dengan judul Islam Syi'ah: Asal-Usul dan Perkembangannya, Cet. I; Jakarta: Pustaka Utama Grafiti, 1989.

al-Thabâthabâ'îy, Islamic Teachings: An Overview, diterjemahkan oleh Ahsin Muhammad dengan judul Inilah Islam: Upaya Memahami Seluruh Konsep Islam Secara Mudah, Cet. I; Jakarta: Pustaka Hidayah, 1989.

al-Thabâthabâ'îy, Sayyid Muhammad Husain, Al-Mizân fî Tafsîr Alquran, Beirut:Mansyurâ Muassasâ al-'Alam li al-Mathbû'ât, 1973. 
Umar, Nasaruddin. Argumen Kesetaraan Gender Perspektif Alquran. Disertasi. Cet. I; Jakarta: Yayasan Paramadina, 1999.

Yunahar Ilyas, Feminisme Dalam Kajian Tafsir Alquran: Klasik dan Kontemporer, Cet. I; Yogyakarta: Pustaka Pelajar, 1997

Az-Zahabiy, Muhammad Husain. Al-Tafsir wa al-Mufassirun. Jilid I. Mesir: Dar alKutub al-Haditsah, 1961.

Zakaria, Ahmad bin Faris. Mu'Jam Maqayis al-Lugah. Beirut: Dar al-Fikr, 1989.

Az-Zamakhsyariy. Tafsir al-Kasysyaf. Mesir: Musthafa al-Baby al-Halabiy, 1992. 